\title{
EFL STUDENTS' METAPHORICAL \\ CONCEPTUALIZATIONS OF LANGUAGE LEARNING
}

\section{CONCEPTUALIZAÇÕES METAFÓRICAS DA APRENDIZAGEM DE LÍNGUAS DE ESTUDANTES DE INGLÊS COMO LÍNGUA ESTRANGEIRA}

\author{
Miguel Farías*** \\ Leonardo Véliz ${ }^{* * *}$
}

\begin{abstract}
Traditional approaches to metaphor have focused primarily on its ubiquity in language and thought. Recently, a growing interest in the pervasiveness of metaphor in modes other than purely linguistic ones has been explored. In this paper particular attention is paid to non-verbal forms of metaphorical depiction. We have examined a small corpus of EFL students' drawings and narratives in order to both tap into their mental representations of what 'language learning' means to them and get closer insights into these learners' belief system. We approach the analysis multimodally, by scrutinizing the various meaning-making potentials of images and text as they conceptualize the learners' perspectives of English language learning. To frame the study of these metaphorical representations, we take Block's (2003) 'acquisition' and 'participation' metaphors and Oxford et al.'s (1998) perspectives on education. Results indicate that most of the visual and narrative metaphorical depictions portray language learning as a dynamic, individual acquisition process and can, therefore, be comprehended primarily through the Learner-Centered Growth perspective.

Keywords: multimodal metaphor; learner beliefs; language learning.
\end{abstract}

\section{RESUMO}

Os enfoques tradicionais da metáfora se centram principalmente em sua localização na linguagem e no pensamento. Um interesse recente tem sido o avanço da metáfora em outros modos de expressão além daqueles puramente linguísticos. Nesse trabalho se coloca ênfase nas forma não verbais de representação metafórica. Observa-se um pequeno corpus de desenhos e narrativas de estudantes de inglês como língua estrangeira com o fim de pesquisar suas representações mentais com relação ao que significa para eles aprender uma língua e para obter uma visão próxima ao sistema de crenças desses estudantes. A análise leva-se a cabo a partir de um olhar multimodal que permite devassar os diversos potenciais de construção de significados das imagens e dos textos no processo de conceptualizações das perspectivas dos estudantes sobre sua aprendizagem da língua inglesa. A análise destas representações metafóricas centram-se nos modelos de Block (2003), que propõe metáforas de aquisição e de participação e de Oxford et al. (1998), que têm como principio quatro

\footnotetext{
*Universidad de Santiago de Chile, Chile.miguel.farias@usach.cl

** Support for this paper came from DICYT, Universidad de Santiago de Chile.Deakin University

*** Melbourne, Australia. leonardo.v@deakin.edu.au

http://dx.doi.org/10.1590/010318135146185751
} 
perspectivas da educação. Os resultados indicam que a maioria das representações visuais e textuais mostra a aprendizagem da língua como um processo individual de aquisição e que pode ser entendida a partir da perspectiva de Crescimento Centrado no Estudante.

Palavras chaves: metáfora multimodal; sistema de crenças dos estudantes; aprendizagem de línguas.

\section{INTRODUCTION}

In their route to become fluent users of the English language (to eventually teach it), learners construct a series of systems of assumptions, beliefs, perceptions, attitudes and conceptualisations that are generated by their direct experiences, interactions and exposure to different language learning contexts. To the elaboration of such systems, we need to add the contribution of a myriad of other vicarious experiences to which learners are exposed, such as literature, movies, and internet, where they actively engage in virtual and indirect transactions in, and with, the language.

In the field of Second Language Learning (SLL) increasing interest in learner belief systems grew out of the pioneering work of Horwitz (1981) who developed the so-called 'Beliefs About Language Learning Inventory' (BALLI) and administered it to both pre-service language teachers and beginner-level language learners (BROWN, 2009). This generated a growing concern for investigating teachers' and learners' structure and content of the mental states that drive their actions. Since then, extensive research into language learners' beliefs has conclusively demonstrated that these have a profound impact on language learning achievement (e.g. WILLIAMS \& BURDEN, 1997, p. 98) and many contribute to effective L2 acquisition (e.g. BROWN, 2009). Additionally, a substantial body of research (e.g. BREEN, 2001; HORWITZ, 1987) has documented that learner beliefs about language learning have a central role in affecting decision-making processes in language learning and teaching.

On those grounds, no avenue should be left unexplored when it comes to understanding what language learners think of the process they are undergoing. One such path is their metaphorical conceptualizations of language learning. Most research studies tapping into learners' conceptualizations of language learning have focused primarily on capturing their views, opinions, attitudes and perceptions through the use of surveys, questionnaires, interviews and reports (e.g. LEKI \& CARSON, 1994; SLIMANI, 1989; ZIMMERMAN, 1997). However, not much 
research is documented on perceptions of language learning through the analysis of visual metaphors produced by the learners.

Previous school and informal learning experiences plus the role of English in today's societies, all come to the fore when learners are called to visualize and draw their own maps of the language learning process. Having access to these conceptualizations, systems of beliefs and understandings, apart from being an excellent metacognitive exercise for the learners themselves, may shed some light on comprehending the metaphors about language learning that they build.

These drawings from learners of English at a teacher education program, whose ages range from 19 to 25 years, provide ample evidence of both personal and instrumental motivations to learn the language and to, eventually, teach it to other future learners. To approach these drawings as metaphorical expressions of the learners' language acquisition process we frame them in the analytical tradition of the Conceptual Metaphor Theory (CMT) and the ensuing recent studies on multimodal metaphors. We proceed to analyse a sample of three drawings and their corresponding narratives to finally draw some conclusions for second language education.

\section{METAPHOR IN LANGUAGE AND THOUGHT}

Metaphor is an old philosophical concern which dates back to Aristotle (KOLLER, 2003). The traditional, and particularly philosophical, view of metaphor holds that it is a device of poetic imagination, rhetorical flourish and a matter of words alone. It is precisely this long-standing philosophical view of metaphor to which work in the late 1970s, especially Ortony's (1979/1993) edited volume, strongly reacted by postulating that metaphor is not just about language but also about how we think about the world. The pervasiveness of metaphor in language and thought only began to be explored in the 1980s as a result of the publication of 'Metaphors We Live By' by Lakoff and Johnson (1980b). This was a central work in the field of metaphor studies as it developed the Conceptual Metaphor Theory (CMT). The theory, as Evans and Green (2006) point out, is one of the first theoretical frameworks of cognitive semantics. The central premise of the CMT is that a metaphor is not simply a stylistic or ornamental device of language; rather, it is something that permeates the ways in which individuals conceptualise the world. Thus, the theory contends that not only is language metaphorical but the nature of thought and how we think about the 
world is also fundamentally metaphorical (EVANS \& GREEN, 2006). What this suggests is that all the reasoning we do and language we express have emerged from our early experiences in the world, particularly from our sensorimotor and bodily interactions with the concrete reality.

An important observation about a conceptual metaphor (CM) relates to its constitution. It is comprised of two levels: a conceptual level and a linguistic one. While the latter refers to either the lexical or phrasal choices the speaker or writer has made to convey a particular message, the former alludes to the overall conceptual structure and mental representations which underpin the linguistic level that shapes and frames the lexical or phrasal choices made by the speaker or writer. For instance, if a speaker or writer uses linguistic expressions such as investing, commitment, compromises, deals, wasting, profits etc. when talking about love, we could say that the conceptual structure or mental schema underpinning those linguistic expressions is one based on viewing or conceptualising love in terms of enterprise or business. The conceptual level is translated into the linguistic level in terms of viewing the lovers as though they were the two parties or companies involved in the business, their profits as achievements during the course of their relationship, investing as putting effort and time in making the business successful. In this way, when unpacking metaphors in language or discourse, one should bear in mind what lies behind the linguistic level and pay attention to the conceptual system that provides an account of how, for instance, a language user views or conceptualizes a particular phenomenon.

This two-dimensional view of metaphor has been one of the major contributions made by cognitive semantics, in particular by the theory of conceptual metaphor. Metaphor is no longer viewed as an extraordinary ornamental device in language; rather, it is now understood as an ordinary phenomenon driven by our conceptual structure and mental representations manifesting itself in the language we regularly use. Although the CMT is regarded by some scholars as 'a major revolution in the study of metaphor' (GIBBS, 2011, p. 529), it has been the object of severe criticism by others.

One of the most serious concerns relates to the narrow scope of the theory. Steen (2011, p. 27) criticises the cognitive-linguistic framework for being too "limited for addressing a number of crucial issues about metaphor, for which a more encompassing interdisciplinary approach is required". He goes on to point out that CMT is not just a matter of language and thought, but also of communication. In order to tap into metaphor from a three-dimensional perspective (language, thought and communication), he argues that a social approach is needed. Such approach 
should allow for analysing forms other than language through which metaphorical meanings are communicated. Steen (2011) as well as other metaphor scholars(e.g. CIENKI \& MÜLLER, 2008; FORCEVILLE \& URIOS-APARASI, 2009) propose that a new and improved version of the CMT should account for alternative forms of metaphorical expression outside language such as gesture, images and all other modes of symbolization.

In this study, the metaphor analysis we attempt to undertake involves the three dimensions discussed above. We will analyse learners' visual metaphors (metaphor in images) in search of the underlying metaphorical conceptual structure (metaphor in thought) motivating the metaphorical depictions along with an analysis of the metaphors embedded in learners' written entries (metaphor in language). This three-dimensional approach is an approximation to what Forceville \& Urios-Aparisi (2009) call a multimodal metaphor analysis.

\section{MULTIMODAL METAPHORS AND METAPHORS IN LANGUAGE LEARNING}

The idea that metaphor is pervasive in different semiotic modes in human communication has been embraced by scholars with an increasing interest in multimodality and cognitive linguistics (see PINAR, 2013). The concept of multimodal discourse came to the fore as a result of studies dealing with the semiotic dimension of language representation (KRESS, 2010; KRESS \& VAN LEEUWEN, 2001, 2006). For some time now and with the massive use of computers and other technological gadgets known as information and communications technologies (ICTs), texts people read come with images and various layouts that contribute to the creation of meaning in those texts.

At the same time, attention to the visual dimension in language production and comprehension has only recently been triggered by studies in multiliteracies and multimodality (e.g. KRESS, 2003; KRESS \& VAN LEEUWEN, 2006). Research in these areas has focused on the architecture of discourse by looking at different semiotic resources such as language, images, gesture and sound, and how these are co-deployed across modalities (KRESS \& VAN LEEUWEN, 2006); still, there is also a need to understand how these modes are retutilised and 'orchestrated' to make new meanings -resemiotization (IEDEMA, 2003). Besides acknowledging language as a powerful meaning-making resource, Adami and Kress (2014) comment on the pressing need to consider multimodal semiotic resources as fundamental contributors to a satisfactory approach to how people engage in meaning making. A 
powerful semiotic resource with a great deal of propositional content is what is called 'pictorial images' (SEDIVY, 1997, p. 95). The propositional content of pictorial images can be metaphorical or literal. Unlike the content of literal depictions, the content of a metaphorical image (or visual metaphor) requires a mapping between two domains of knowledge. This is clearly exemplified by Forceville and UriosAparisi (2009) who point out that in order to understand, for instance, corporate branding (one domain of knowledge), it is necessary to rely on our knowledge of people (another domain of knowledge) endowed with such traits as growth, flexibility, dynamism, connectivity, amongst others.

Multimodal social semiotics has proved to be relevant to central areas of education (BOURNE \& JEWITT, 2003). As a theory it provides a dual focus: on the agency of the makers of signs in social environments and on the resources used in the making of signs. The theoretical and descriptive tools of social semiotics provide the means to see sign- and meaning-making as learning; and they allow learning to be seen as an instance of sign- and meaning-making. Multimodality provides the tools for the recognition of all the modes through which meaning has been made and learning has taken place.

The relevance of this model is ascertained by Low (2003, p. 239) when he writes "with the development of social semiotic approaches to language and literacy, and particularly of conceptual metaphor theory, metaphoric models have become increasingly popular as means for examining the nature of language teaching and learning". In this line, Low (2003) examined a group of five metaphoric models referred to language teaching/learning in search for a sound methodology to evaluate these models. Finding the models flawed, the author comes up with a set of eight proposals for the design, analysis and evaluation of metaphoric models. Even though they may be more metonymic, or plain analogies, in their particular contexts, some of the models reviewed by Low, such as "L2 learning is L1 learning", "the teacher is a providing parent", "teacher as researcher", or "teacher as nurturer", might be behind the visual metaphors we investigated. Participants in this study are not only learning English but they are learning this second language with the purposes of teaching it and, thus, are at the same time constructing their teacher identity. Then, of particular interest for this research are the metaphors discussed in one the models evaluated by Low, those in Oxford et al (1998) whose typology includes four perspectives: Teaching as Social Order, Cultural Transmission, Learner-Centred Growth and Social Reform. Oxford et al (1998) discuss these four perspectives in terms of three key aspects: Control, Focus, and Archetype. For example, the Learner- 
Centred Growth and Social Reform perspectives are characterized as having shared teacher-and-student control, whereas in the Teaching as Social Order and Cultural Transmission perspectives the teacher is in control. In the LearnerCentred Growth view the focus is on facilitating development of innate potential, and the archetype is gardening. Although these perspectives apply to any area of education, here they are used to understand the visual metaphors in the sample analysed. In addition to that, another reference to keep in mind in the analysis is the distinction made by Block (2003) between 'acquisition metaphor' and 'participation metaphor' which might reveal the curricular orientations of the program these learners belong to. At this point, at least in Latin America, the curricular tensions evidenced in language education programs are between cognitive and sociocultural models of language learning.

\section{THE STUDY}

The context in which our study was undertaken can be identified as what Graves (2008, p. 155) calls a "target-language removed" setting. This refers to a context where the language used by the community surrounding the language classroom is distinct from the target language. This implies that few affordances are usually available outside the classroom for language learners to expose themselves to instances of target language use in the wider community. The participants who consented to take part in this study are all Chilean university students at an English as a foreign language (EFL) teacher education program. The students, whose first language is not English, have been studying the English language for over three years. As part of their teacher education program, the learners have already undertaken several field-specific subjects, such as teaching methodology, theories of language learning, amongst others.

Participants were a group of 12 students (10 female and 2 male) in an English as a foreign language teacher education program. They were asked to draw images prompted by the question: how do you visualize your language learning process? Students from the 2012 group were shown samples of previous visual metaphors by learners from another group as references for their own drawings. However, the samples of visual metaphors shown to participants responded to a different prompt question that had been given to the previous group. In this way, it can be ascertained that such procedure did not influence the students' production of metaphorical depictions. 
Of the 12 drawings and narratives by students, three were randomly selected for the purpose of the analysis.

\section{METHODS}

In the examination of learners' perceptions of language and language learning, a number of methods utilised to elicit data are well documented. Questionnaires (MINOR, ONWUEGBUZIE, WITCHER, \& JAMES, 2002; PARPALA, LINDBLOM- YLÄNNE \& RYTKÖNEN, 2011), interviews (BARKHUIZEN, 1998; KUO, 2011), students' composition and observations (BARKHUIZEN, 1998) and drawings (SWALES, 1994) have been some of the well-known methods used in the elicitation of data. In our study, data were gathered from two sources. One was students' images while the other was a written composition by learners. It was decided that learners' images and narratives were a reasonable method to adopt in this investigation as this would give us dual insights into their metaphorical conceptualisations of language learning. Following recent trends in the study of metaphor, looking at these two dimensions allowed us to see the various relationships between image and text.

Throughout the analysis the following coding system will be used. Each of the three pictorial metaphors will be referred to as VM1, VM2 and VM3 respectively where 'VM' stands for 'Visual Metaphor'. Reference to the learners who produced these VMs is made by L1, L2 and L3 respectively where 'L' stands for 'learner'. The three sample narratives are in the Appendix.

\section{ANALYSIS}

Multimodal discourse analysis allows us to look at each drawing as a result of a sign and meaning making process. We look at the production of these drawings from a multimodal analysis view that considers all options learners take in selecting the shapes, colours, layout and sizes to depict what they understand as second language learning. The metaphorical meanings portrayed in these visuals are discussed in connection with the narratives that describe them. Behind such options there is an epistemological commitment that materially shapes the textuality of the concepts needed to convey the meanings prompted by the question "What 
is second language learning for you?" The major challenge for learners is that this time writing is not the only means by which they express their meanings but a visual depiction of them.

a) Visual Metaphor 1

The first VM illustrates second language learning as a dynamic process that involves a path to (usually) the world. As seen in Fig. 1, such path is a labyrinth that connects various cultures to get to know the world.

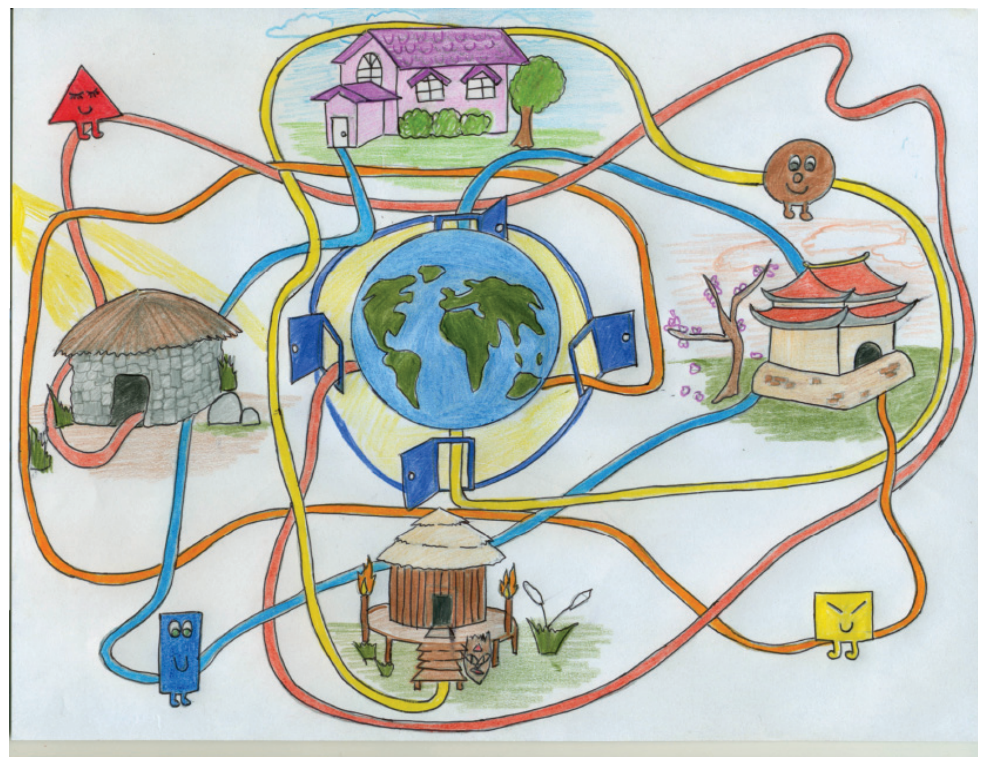

Fig. 1. Visual metaphor 1 from learner 1 (VM1, L1)

The complexity of the network of paths in this amazingly meaningfully fertile VM may be indicative of several possible things. First, it may suggest that the learner views language learning as a non-linear system, notion that aligns with Larsen-Freeman's (1997) review of 'chaos complexity theory' for which learning is understood as a dynamic, complex non-linear process. An interesting metaphor depicted in how the complex paths interconnect with each other is that of 'connectivity' in the roads or paths that cross the world and unite the various homes that the language learner encounters. Although the metaphor of connectivity has been widely used within the context of the World Wide Web, as Carroll (1996) 
stated, it is a metaphor that clearly reveals the learners' thinking about language learning. This connectivity can also be appreciated in L1's written entry where the following comment can be observed:

"...English learning takes us out of our close environment and culture to the rest of the world..." (L1, Appendix).

The metaphorical use of the phrasal verb take out and the adjective close provides evidence of not only the connectivity but also of the 'containment' metaphor underlying the learner's mental structure. As Kövecses (2010) points out, the metaphorical nature of certain word-class items is not arbitrary but a systematic indication of people's conceptual patterns of thought. Being out of a close environment suggests the possibility of access to connect with what lies outside an enclosure. Such access is made possible by the four doors located at the 'four corners of the world' through which paths come out wriggling around finding their way into different home styles. This indicates that L1 conceptualizes learning English as not only a means whereby people from diverse cultures are brought together but also as a tool that opens doors and, therefore, affords individuals with the capacity to access, what L1 calls, new realities. This is clearly exemplified in the following quote:

"... the paths represent the long and demanding process by which we learn and get to know other realities..." (L1, Appendix).

In brief, this learner's overall conceptualization of language learning is summarized in the following comment:

"...I see the English learning process as a long, not easy one, that joined people together" (L1, Appendix)

Not only does this proposition reiterate the underlying metaphor of learning as a complex process depicted in the network of paths discussed earlier, it also highlights the culturally diverse salience represented by the different house styles which seem to cue not only the metaphor of English as a 'tool' that brings people together but also that of English as a door to the world.

b) Visual Metaphor 2 
Interestingly enough, learning seems to be depicted as an individual process as all participants visualize themselves as single learners; classmates or other learners are not incorporated in these metaphors. One of them, see Fig. 2, is even connected to the earphones as he treads his own path to the world of English teaching. This metaphor coincides with Hager (2008, p. 679) when he discusses what he calls the 'common-sense' story about learning where "the most desirable learning is located in the individual minds"

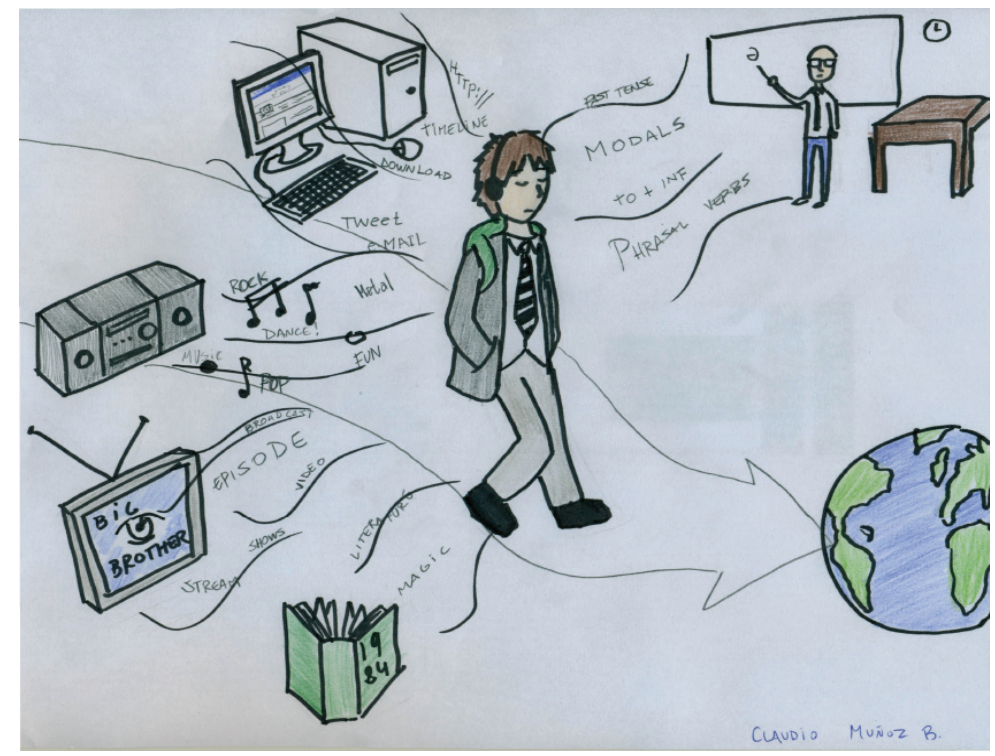

Fig. 2.Visual metaphor 2, learner 2 (VM 2, L2).

While connectivity in L1 refers to the world out large, L2 is connected to the multiple technologies through which he gets linguistic input. This input seems to provide a comfortable path to travel into the world, a road signalled by the arrow.

In the narrative by L2, he refers to this input as follows:

"... he receives English language from different sources. Some of them are related to learning (the school, the teacher and the book) and others with acquisition (TV, radio, etc.)" (Learner 2, Appendix).

The distinction L2 makes between learning and acquisition may suggest that his learning process has encompassed both formal and informal exposure to English. This learner has, in fact, received university instruction on theories of language learning. The learner's explicit reference to the acquisition-learning 
divide in the narrative is indicative of how his previous experiences and encounters with language have influenced his beliefs, perceptions and overall thinking. This is supported by Lakoff and Johnson's (1980a, 1980b, 1999) basic tenet of the theory of $\mathrm{CM}$ which indicates that the way in which individuals speak and think about the world is influenced by previous experiences and interactions with it. These previous experiences have certainly had an impact on how this learner has come to conceptualize language learning as reflected in both the narrative and the visual metaphor.

Despite the learner's clear distinction between learning and acquisition, he considers these two sources of input as equally valuable to his second language learning process when he mentions:

"Every item contribute in a way to the understanding of English" (Learner 2, Appendix).

The learner's recognition that every single source of input is a contributor to his language learning experience is quite significant since it is a reflection of his capacity to deepen his understanding of English, as he states, through the interaction with multiple modes of information and communication. In this way, the learner's overall conceptualization of learning reveals the complex ways in which multiple resources for meaning-making available to the learner interact with each other and with the individual to contribute to a multimodal learning experience.

c) Visual Metaphor 3

The third pictorial metaphor used in the sample for analysis appears to suggest that the learner (L3) sees language learning as both a purely mental process depicted by a clockwork mechanism in the head and as an output machine as shown in the language produced as speech; both of which reflect Block's (2003) acquisition metaphor. 


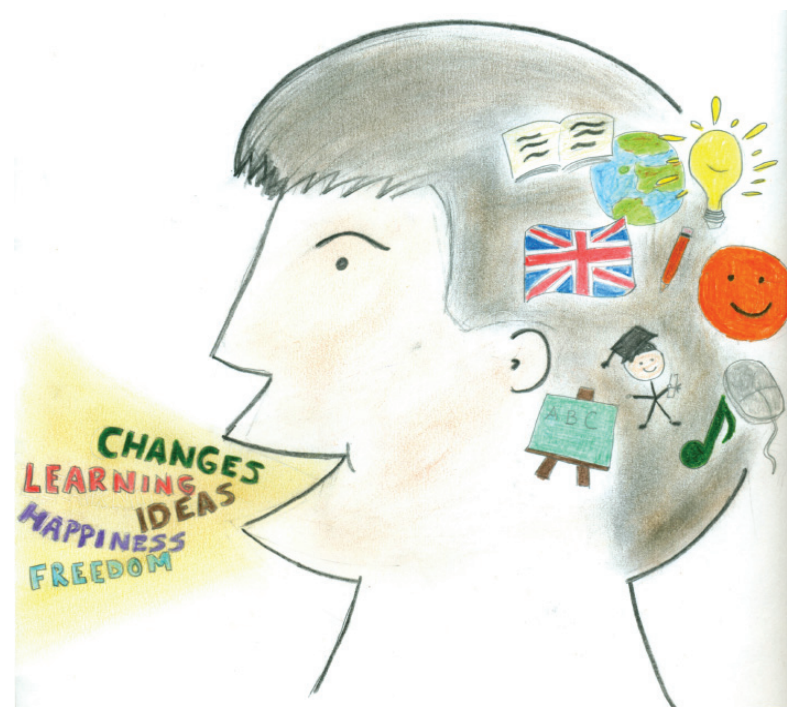

Fig. 3. Visual Metaphor 3, Learner 3 (VM3, L3)

In terms of Oxford et al.'s (1998) model the educational perspective this learner represents is Learner-Centered Growth as the input she receives seems to facilitate the development of her potentialities. This cognitive dimension is illustrated by the focus on the learner's head and references to the various linguistic inputs that constitute the language learning process. Some of these such as the teacher, the book and the whiteboard represent formal education; others (flag and world) depict cultural aspirations. Simultaneously, language learning is also portrayed as output in the form of concepts that, as supported by the narrative, have been internalised:

"... all that we learn is stored in our beads and then, once we've internalised it we're able to put that in practice by means of new ideas, concepts, etc." (L3, Appendix )

These concepts synthetize the expectations this language learner has placed on the teaching and learning of a second language: changes, learning, ideas, happiness and freedom. These are associated with her positive engagement as a learner:

"Learning English is something that I really like and makes me bappy" (L3, Appendix ) 
L3 reiterates the metaphor used by L1 regarding the learning of English as a door to the world when she writes:

"I consider that it opens a door to know the world and to develop our intelligence" (L3, Appendix ).

This statement also ratifies the metaphorical appreciation of learning as an individual endeavour shared by all participants in their pictorial and narrative accounts.

\section{CONCLUSIONS}

The sample of visual metaphors and narratives analysed in this study provide an overview of how language learning is metaphorically conceptualised by learners at a Chilean English teacher education program. The three visual and written narrative metaphorical representations share the common perspectives these learners have towards learning English. These include the complex and individual nature of language learning as well as the possibilities it offers to interconnect with the world. Most importantly, language learning is regarded as a pleasant and growing experience. They may also embody at least two of the four models found by Oxford et al. (1998), which are Cultural Transmission and Learner-Centered Growth.

The analysis has also revealed that these learners are familiar with the metalanguage in applied linguistics in the form of such distinctions as 'acquisition' and 'learning', 'input' and 'output', and the use of concepts such as 'internalization', 'processing' and 'storage of information'. Apparently, acquisition, and not participation, is the dominant metaphor for these learners as we see them individually engaged in the learning process, with the teacher playing a complementary role among other sources of linguistic input.

In line with current and abundant research on teachers' beliefs, these visual metaphors offer a window into preservice teachers' beliefs about learning and teaching. In this respect, we concur with Farrell (2006) when he concludes that by articulating their beliefs through metaphors, "they can become more aware of the origin of these beliefs and can then decide whether these metaphors remain valid and useful for their particular context" p. 247.

The analysis of these visual metaphors from the perspectives of the social semiotic approach to literacy and the CMT renders valuable methodological, conceptual and pedagogical insights into second/foreign language learning fonts 
of knowledge. These ideas well echo Oxford et al.'s (1998, p. 46) claims that "considering carefully various metaphors and underlying beliefs can be of particular assistance in widening perspective-consciousness about classroom events, style conflicts and instructional methods".

For language educators these visual metaphors offer an infinite number of pedagogical possibilities. The analysis here included can be extended to image/ text relationships (UNSWORTH, 2006; SALWAY \& MARTINEC, 2005) such as complementarity or concurrence, to deploy metacognitive strategies by asking learners to describe orally their drawings, and to illustrate theories of language learning.

Since the study was limited to data collected cross-sectionally, it was not possible to assess evolutionary changes in the learners' conceptualizations of language learning. To capture the process and development of their perceptions, longitudinal data should be gathered. In this case, having access to more comprehensive data over a period of time would enable the researchers to have not only a clearer view of how language learning is conceptualized over time but also how such views and perceptions may be indicative of learners' construction of teacher identity.

\section{REFERENCES}

ADAMI, E.; KRESS, G. (2014). Introduction: multimodality, meaning making, and the issue of "text". Text and Talk. v. 34, no 3, pp. 231-237.

BARKHUIZEN, G. (1998). Discovering learners' perceptions of ESL classroom teaching/ learning activities in a South African context TESOL Quarterly. v. 32, $\mathrm{n}^{\circ} 1, \mathrm{pp} .85-$ 108.

BOURNE, J.; JEWITT, C. (2003). Orchestrating debate: a multimodal approach to the study of teaching of higher literacy skills. Reading: Literacy and Language, UKRA(July), pp. 64-72.

BREEN, M. (2001). Learner contributions to language learning: New directions in research. Harlow, UK: Pearson Education Limited.

BROWN, A. (2009). Students' and teachers' perceptions of effective foreign language teaching: a comparison of ideals. The Modern Language Journal. v. 93, n ${ }^{\circ}$ i, pp. 46-60.

CARROLL, N. (1996). A note on film metaphor. Journal of Pragmatics. v. 26, nº 6, pp. 809822.

CIENKI, A.; MÜELLER, C. (Eds.). (2008). Metaphor and gesture. Amsterdam/Philadelphia: John Benjamins.

EVANS, V., \& GREEN, M. (2006). Cognitive linguistics: An introduction. Edinburgh: Edinburgh University Press. 
IEDEMA, R. (2003). Multimodality, resemiotization: extending the analysis of discourse as multi-semiotic practice. Visual Communication, v. 2, $\mathrm{n}^{0} 1$, pp. 29-57.

FARRELL, T. (2006). The teacher is an octopus: uncovering preservice English language teachers' prior beliefs through metaphor analysis. Regional Language Centre Journal. v. $37, \mathrm{n}^{\circ} 2$, pp. 236-248.

FORCEVILLE, C. J.; URIOS-APARISI, E. (Eds.). (2009). Multimodal metaphor. Berlin Mouton De Gruyter

GIBBS, R. (2011). Evaluating conceptual metaphor theory Discourse Processes. v. 48, pp. 529562.

GRAVES, K. (2008). The language curriculum: A social contextual perspective. Language Teaching. v. 41, $\mathrm{n}^{\mathrm{O}} 2$, pp. 147-181.

HAGER, P. (2008). Learning and metaphors. Medical Teacher. v. 30, pp. 679-686.

HORWITZ, E. (1981). Beliefs about language learning inventory. Unpublished manuscrit. The University of Texas at Austin.

HORWITZ, E. (1987). Surveying student beliefs about language learning. In: A. Wenden \& J. Rubin (Eds.), Learner strategies in language learning. London: Prentice Hall.

KOLLER, V. (2003). Metaphor Clusters in Business Media Discourse: A Social Cognition Approach Department of English Unpublished Ph.D. Dissertation, University of Vienna, Vienna, Austria.

KÖVECSES, Z. (2010). Metaphor: A practical introduction (2nd ed.). Oxford: Oxford University Press.

KRESS, G. (2003). Literacy in the new media age. London: Routledge.

KRESS, G. (2010). Multimodality: A social semiotic approach to contemporary communication. New York: Routledge.

KRESS, G.; VAN LEEUWEN, T. (2001). Multimodal discourse: The modes and media of contemporary communication. London: Edward Arnold.

KRESS, G.; VAN LEEUWEN, T. (2006). Reading images: the grammar of visual design. London: Routledge.

KUO, I.-C. (2011). Student perceptions of student interaction in a British EFL setting ELT journal. v. 65, nº 3, pp. 281-290.

LAKOFF, G.; JOHNSON, M. (1980a). Conceptual metaphor in everyday language. The Journal of Pbilosopby. v. 77, n ${ }^{\circ} 8$, pp. 453-486.

LAKOFF, G.; JOHNSON, M. (1980b). Metaphors We Live By. Chicago University of Chicago Press.

LAKOFF, G.; JOHNSON, M. (1999). Philosopby in the Flesh: The Embodied Mind and the Challenge to Western Thought New York Basic Books

LARSEN-FREEMAN, D. (1997). Chaos/complexity science and second language acquisition. Applied Linguistics. v. 18, n 2, pp. 141-165.

LEKI, I.; CARSON, J. (1994). Students' perceptions of EAP writing instruction and writing needs across the discisplines. TESOL Quarterly. v. 28, nº 1, pp. 81-101. 
LOW, G. (2003). Validating metaphoric models in Applied Linguistics. Metaphor and Symbol. v. $18, n^{\circ} 4$, pp. 239-254.

MARTINEC, R.; SALWAY, A. (2005). A system for image-text relations in new (and old) media. Visual Communication. v. 4, pp. 337-371.

MINOR, L.; ONWUEGBUZIE, A.; WITCHER, A.; JAMES, T. (2002). Preservice teachers' educational beliefs and their perceptions of characteristics of effective teachers. The Journal of Educational Research. v. 96, nº 2, pp. 116-127.

ORTONY, A. (Ed.) (1979/1993). Metaphor and thought: Second edition. Cambridge: Cambridge University Press.

OXFORD, R.; TOMLINSON, S.; BARCELOS, A.; HARRINGTON, C.; LAVINE, R.; SALEH, A.; LONGHINI, A. (1998). Clashing metaphors about classroom teachers: toward a systematic typology for the language teaching field. System. v. 26, pp. 3-50.

PARPALA, A.; LINDBLOM-YLÄNNE， S.; RYTKÖNEN, H. (2011). Students' conceptions of good teaching in three different disciplines Assessment and Evaluation in Higher Education. v. 36, $\mathrm{n}^{\circ}$ 5, pp. 549-563.

PINAR, M. (2013). Multimodality and cognitive linguistics. Review of Cognitive Linguistics. v. $11, \mathrm{n}^{\mathrm{O}} 2$, pp. 227-235.

SEDIVY, S. (1997). Metaphoric picture, pulsars, platypuses. Metaphor and Symbol. v. 12, $\mathrm{n}^{\circ}$ 2, pp. 95-112.

SLIMANI, A. (1989). The role of topicalisation in classroom language learning. System. v. 17 , pp. 223-234.

STEEN, J. G. (2011). The contemporary theory of metaphor - now new and improved. Review of Cognitive Linguistics. v. 9, no 1, pp. 26-64.

SWALES, S. (1994). From metaphor to metalanguage. English Teaching Forum. v. 32, n 3, para. 8.

UNSWORTH, L. (2006). Towards a metalanguage for multiliteracies education: Describing the meaning-making resources of language-image interaction. English Teaching: Practice and Critique. v. 5, $\mathrm{n}^{\mathrm{O}} 1$, pp. 55-76.

WILLIAMS, M.; BURDEN, R. (1997). Psychology for language teachers. A social constructivist approach. Cambridge: Cambridge University Press.

ZIMMERMAN, C. (1997). Do reading and interactive vocabulary instruction make a difference? TESOL Quarterly. v. 31, pp. 121-140. 


\section{APPENDIX}

\section{Learner 1}

Through this drawing I aim at representing that English learning take us out of our close environment and culture to the rest of the world. The patbs represent the long and demanding process by which we learn and get to know other realities to, finally, open a door to the world. The figures represent the individual differences both physical and cultural learners may bave. In brief, I see the English learning process as a long, not easy one that joint people together.

\section{Learner 2}

My drawing has a boy walking towards a globe (a symbol for globalization), and be perceives English language from different sources. Some of them are related with learning (the school teacher, the book) and others with acquisition (TV, radio). Every item in a way contribute to the understanding of English.

\section{Learner 3}

English for me represents many things. When I think about the English learning process I also think about travelling, having access to new knowledge and of course about being a teacher.

I believe that all that we learn is stored in our heads and then, once we've internalised it we're able to put that in practice by means of new ideas, concepts, etc.

Learning English is something that I really like and makes me bappy. I consider that it opens a door to know the world and to develop our intelligence.

Recebido: 08/07/2016

Aceito: 31/10/2016 


\section{ERRATA}

Artigo: EFL STUDENTS’ METAPHORICAL CONCEPTUALIZATIONS OF LANGUAGE LEARNING

Publicação: Trab. linguist. apl. v55n3a12, 833-850, Campinas set./dez. 2016

DOI: bttp://dx.doi.org/10.1590/010318135146185751

Pág 833. - Inverter ordem das instituições e inclusão de uma nota no primeiro autor nas notas de rodapé

Onde se lia:

*Deakin University, Melbourne, Australia. leonardo.v@deakin.edu.au

** Universidad de Santiago de Chile, Chile.miguel.farias@usach.cl

Leia-se:

*Universidad de Santiago de Chile, Chile.miguel.farias@usach.cl

** Support for this paper came from DICYT, Universidad de Santiago de Chile.

${ }^{* * *}$ Deakin University, Melbourne, Australia. leonardo.v@deakin.edu.au 